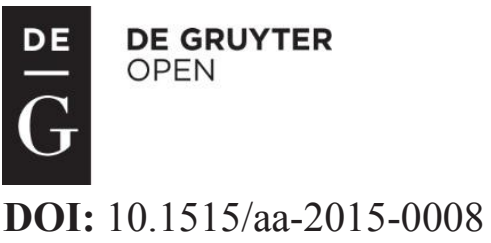

\title{
A man in crisis: selected short fiction of Joseph Conrad
}

\section{Simona Klimková}

Simona Klimková is an assistant professor at the Department of English and American Studies of the Constantine the Philosopher University in Nitra, Slovakia, where she lectures and teaches courses on British and postcolonial literature. Her research focuses primarily on the areas of postcolonial studies and postcolonial writing. Dr Klimková is the co-author of the following monographs: Cultural encounters in contemporary literature; Multicultural awareness: reading ethnic writing; and Literature and culture.

\begin{abstract}
Joseph Conrad devoted twenty years to the writing of short stories. The wide range of subject and setting, spanning from sea stories to domestic tales, managed to constitute Conrad's reputation as a master story-teller capable of capturing his audience with any theme. While the stories vary in quality, length and themes explored, they all oscillate around the subject of human psyche, with its unpredictability and dark corners portrayed in a rather complex way. The paper seeks to explore the vision of humanity, emerging from Conrad's short fiction, as well as the literary devices which enable him to capture the essence of human struggle. It focuses primarily on Conrad's extensive use of figurative language, which contributes to the lyrical quality of his texts, and enables him to express the anguish and disintegration of his characters.
\end{abstract}

Joseph Conrad devoted twenty years to the writing of short stories. Published in seven volumes between the years 1886 and 1916, they vary in length and quality. Due to the lucrative short-story market, the form "was well-paid, yielding a much greater return for effort than the longer work" (Simmons, 2006, p. 156). For reference, "[i]n 1901, when average earnings were around $£ 100$ per annum, Conrad earned $£ 40$ for 'Amy Foster', a story of 12,500 words“ (ibid.). Therefore, some of his short fiction was motivated by the prospect of immediate financial benefit rather than artistic vocation (hence the difference in quality). During that time, however, Conrad also experimented freely with both the form and the subject of his tales and they soon became the playground in which the themes of some of his famous novels were first explored. Moreover, when "he constructed his novels, Conrad began with an episode, or 'moral pivot', and multiplied its implications as he developed his narrative line" (Fraser, 1996, p. 27). In other words, most of his novels started out as sketches or short tales. 
The volumes containing Conrad's short fiction explore various themes although the writer himself believed that "every volume of [his] short stories has a unity of artistic purpose, a mood of feeling and expression, which makes it different from every other" (Conrad quoted in Davies and Moore, 2008, p. 300). Some critics, however, point to the fact that such an intrinsic unification is, in some cases, questionable. Conrad's first collection, Tales of Unrest (1898), for example, is set mainly in the colonial world (with which Conrad is mostly associated with) and the plot develops in such locales as Congo or Malayan archipelago; the story The Return, however, dramatizes a highly domestic scene and focalizes on marital bond. In $A$ Set of Six (1908), the stories are linked through a unifying principle of tonal quality. Each tale is attributed a different tone - The Brute is subtitled An Indignant Tale, An Anarchist on the other hand is marked as $A$ desperate Tale, although their subject matters vary. Nevertheless, the wide range of subject and setting, spanning from sea stories to domestic tales, managed to constitute Conrad's reputation as a master story-teller capable of capturing his audience with any theme.

While Joseph Conrad is often described as a writer of adventurous stories, it is not, in fact, the exotic location that the writer is interested in. It is rather the human psyche, with its unpredictability and dark corners accounting for Conrad's trademark pessimism, which fascinates him most and plays a crucial role in his writing. Some of Conrad's characters are driven by idealism, others by greed, ignorance or misplaced ambition; all of them, however, end in a disaster of some kind. The vision of humanity, emerging from Conrad's texts, is thus not very optimistic. They contemplate on moral corruption, disintegration and disillusionment which frequently lead to frustration and total despair or destruction.

Despite its dark thematic scope, Conrad's writing displays an immense sense of lyricism and poetic beauty. His mastery of the English language and his subtle use of imagery and symbolism prove that he was a gifted storyteller with a talent for evocative portrayal. Fiction, according to Conrad, "appeals to temperament. And in truth it must be, like painting, like music, like all art, the appeal of one temperament to all the other innumerable temperaments whose subtle and resistless power endows passing events with their true meaning, and creates the moral, the emotional atmosphere of the place and time" (Conrad, 1897/1914). The dense, yet masterful, use of sensual imagery immediately transports the reader to the setting of the story and involves him/her in its moral predicament.

While the narratives differ both formally and thematically, the majority of Conrad's short stories share his number one trademark feature, namely the frame narrative (perfected in his masterpiece Heart of Darkness). Structured as tales-within-tales, the stories foreground the 
problem of interpretation, especially with regard to the motivation and involvement of the speaker and his relation to the content of the narrative. The device of the dual narrator enables Conrad to distance one speaker from the events described, while the second narrator remains deeply involved and engaged in the story he is telling. Usually, the background details and context specification are provided by the first narrator, often anonymous, who then recedes to the background and assumes the role of a listener as the story-telling is handed over to the second narrator. While the first narrator is not emotionally involved in the narrative and functions more or less as an observer and mediator, the second narrator is typically a direct participant of the events. The first-person narration, employed in the latter part of the story, constitutes the effect of oral transmission. At the end, the narration is again resumed by the initial narrator who also provides certain closure.

The use of the frame method can be exemplified by the short story The Lagoon, from his first collection Tales of Unrest, which takes place in a remote lagoon somewhere near the Malay Peninsula. The beginning of the story is rendered in a third person narrative voice, centered on an unnamed white man who is in command of a small boat with Malay crew. As they arrive in the isolated lagoon, the narration is taken over by Arsat, a Malay man and an acquaintance of the white man, who lives in the lagoon with his lover Diamelen. As she is lying on her deathbed, Arsat recounts the story of how Diamelen, at the time a servant of rajah's wife, eloped with him and how his brother helped them to escape from rajah's men, eventually losing his life in a fight. Arsat struggles with a destructive feeling of guilt, as it was him who betrayed his brother, while the white man witnesses his mental torment. At the end of the story, which climaxes with Diamelen's death, the white man leaves the lagoon and leaves Arsat motionless and paralyzed in the wilderness.

From the very beginning, the story diffuses an atmosphere of stillness, silence and immobility. As the boat "enters the portals of a land from which the very memory of motion had forever departed" (Conrad, 1897), Conrad builds the suspense through a highly evocative description of the natural surroundings.

"The forests, somber and dull, stood motionless and silent on each side of the broad stream. At the foot of big, towering trees, trunkless nipa palms rose from the mud of the bank, in bunches of leaves enormous and heavy, that hung unstirring over the brown swirl of eddies. In the stillness of the air every tree, every leaf, every bough, every tendril of creeper and every petal of minute blossoms seemed to have been bewitched into an immobility perfect and final" (ibid.). 
The detailed description of the scenery, intensified by an extensive use of figurative language, creates an immediate contrast between the land and the moving boat. It seems as if the stream is protesting against the boat's movement, its advancing feels like intrusion, violating the will of the land. The vividness of detail, employed in the depiction of the nature, gives the wilderness a very material quality; its presence and power are imminent, even personified. Emphasizing the sombre stillness and motionlessness of the jungle, the opening imagery corresponds to the stagnancy of the lagoon which reflects the apathetic life of Arsat. The symbolic connection between the environment and Arsat's inert and putrid existence, reminiscent of Kurtz and the African jungle in Heart of Darkness, is skilfully captured in Conrad's detailed sensory depictions. The writer, in fact, emphasized the significance of sensuality as one of the fundamental qualities of literature by claiming that:

\begin{abstract}
"All art $[\ldots]$ appeals primarily to the senses, and the artistic aim when expressing itself in written words must also make its appeal through the senses, if its high desire is to reach the secret spring of responsive emotions. It must strenuously aspire to the plasticity of sculpture, to the colour of painting, and to the magic suggestiveness of music - which is the art of arts. And it is only through complete, unswerving devotion to the perfect blending of form and substance; it is only through an unremitting never-discouraged care for the shape and ring of sentences that an approach can be made to plasticity, to colour, and that the light of magic suggestiveness may be brought to play for an evanescent instant over the commonplace surface of words [...]" (Conrad, 1897/1914).
\end{abstract}

In that sense, no detail is small enough to be recorded in order to bring the visual scenery to life. In The Lagoon, the sensory impressions are built upon the contrast of light and darkness, the stagnancy of the lagoon and the movement of both the stream and the boat, as well as upon the intense capturing of colour. Moreover, the evocative quality of the text is strengthened by the frequent use of alliteration and assonance [for example, "we skirted the sand beaches where the sea speaks in whispers to the lands" (Conrad, 1897, emphasis added) or "in the dim light of the dwelling" (ibid., emphasis added)], simile, anaphora, personification and metaphors. In fact, Conrad's language strongly resembles that of a poet; he is clearly concerned with the power of words to stir up vivid images in the mind of his readers so that they achieve the desired plasticity and suggestiveness.

The language is, of course, employed in a highly functional manner. Its aim is to point at the mental anguish Arsat experiences since his beloved's death is quickly approaching, which brings back memories of his betrayal. Tormented by despair and remorse, Arsat represents a man in crisis, isolated from the rest of the world so that his agony is intensified to 
a peak level. It is therefore not the exotic scenery, though described in such an animated detail, that the writer is interested in; it is the man himself that stirs up Conrad's attention. Arsat's egoistical decision to run away with Diamelen instead of saving his brother's life casts a dark shadow over his existence. After her death, he intends to resurrect his former identity and avenge his brother's death, a futile endeavor in the eyes of the white man which can only result in Arsat's death. As the white man leaves the lagoon, he sees Arsat "still looking through the great light of a cloudless day into the hopeless darkness of the world" (Conrad, 1897). The ending thus demonstrates "that serenity always lies beyond the reach of those who pursue self-interest or are haunted by the consequences of their previous actions" (Billy, 1997, pp. 171-172).

Conrad's last short story The Tale, from the collection Tales of Hearsay, dramatizes a similar problem. Again, the frame narrative is employed to introduce a story of a Commanding Officer and a Northman told by a nameless man to a woman, presumably his lover who requested to hear it. Set during the First World War, The Tale recounts the mysterious encounter of two ships in the North Sea with fatal consequences. When the Commanding Officer spots a suspicious ship and suspects that they might provide supplies for their enemies, he orders the Northman (captain of the other ship), who claims he does not know his location because of the fog, to leave the cove. To test the credibility of Northman's words, he gives him false directions which eventually results in the sinking of the ship "on a deadly ledge of rocks" (Conrad, 1916) and the death of the crew. The Commanding Officer is then plagued by guilt since he probably condemned innocent men to death.

Although the frame narrative form suggests that Conrad is blending two narratives here as usual, at the end of The Tale the story-teller reveals his true identity to the woman - he is the Commanding Officer from the story. The fact that he was obscuring his identity at first complies with the theme of confusion and uncertainty which plague the main protagonist. The narrative abounds in words like 'shadow', 'suspicion' and 'certainty' which only reinforce the idea that it is impossible to achieve certitude or distinguish easily between truth and falsity, right and wrong in times of war. As the Northman recapitulates his own story, the officer examines the captain closely and questions his every single utterance. "Was he pretending to be drunk, or only trying to appear sober? His glance was straight, but it was somewhat glazed. His lips outlined themselves firmly under his yellow moustache. But they twitched. Did they twitch? And why was he drooping like this in his attitude?" (ibid.) The repetitive use of questions highlights his own uncertainty and doubts; the form of the narrative thus closely correlates with its thematic scope. The closing pronouncement of the Commanding Officer 
rules out any solution to his dilemma, the truth and thus the absolution is unattainable: "I believe-no, I don't believe. I don't know. At the time I was certain. They all went down; and I don't know whether I have done stern retribution-or murder; whether I have added to the corpses that litter the bed of the unreadable sea the bodies of men completely innocent or basely guilty. I don't know. I shall never know" (ibid.). The comforting provided by the woman is declined as the man disengages himself from her embrace and leaves, to be haunted by his decision for the rest of his life.

Again, Conrad pays close attention to the symbolical rendering of the theme. Just like in The Lagoon, the setting of the story is highly metaphorical. The whole tale opens as "the crepuscular light was dying out slowly in a great square gleam without colour" (ibid.) and the reader is transported to a dark room with a "shadowy couch holding the shadowy suggestion of a reclining woman" (ibid.) The indistinct descriptions of the setting and the participants foreshadow the primary concern of the story that is to follow. Later on, as the narrator recounts his sea adventure, the motif of visibility recurs. As the ship is enveloped by the blinding fog, so is the Commanding Officer uncertain of the morality of his decision. "The ship was stopped, all sounds ceased, and the very fog became motionless, growing denser and as if solid in its amazing dumb immobility. The men at their stations lost sight of each other. Footsteps sounded stealthy; rare voices, impersonal and remote, died out without resonance. A blind white stillness took possession of the world" (ibid.). The inability to see is thus both literal and metaphorical and leaves the officer as well as the reader in the dark about the nature of his order.

In Amy Foster (1901), collected in Typhoon and Other Stories, Conrad explores a rather personal theme. Focused on the unfortunate Central European emigrant known as Yanko Goorall, Amy Foster recounts a story of isolation, loneliness and cultural exclusion. Washed ashore the English coast, Yanko, on his way to America, becomes the only survivor of an immensely tragic shipwreck. Treated with mistrust and abuse by the local community, his integration to the society is extremely slow and painful. The language barrier isolates him from the villagers who see him as a madman or devil and want nothing to do with him. Saving a grandchild of a local farmer from drowning earns Yanko at least some respect but he is never fully trusted and accepted. Amy Foster, a local girl with "a golden heart, and soft to people's misery" (Conrad, 1901), is the only person to treat him humanly. Eventually, they get married and start a family of their own. The family idyll does not last long, however, as Amy too begins to get affected by the prevailing mistrust towards her husband. Suspicious of his occasional ramblings in his native tongue (to introduce his culture to his son) which she does 
not comprehend, Amy interprets them as a sign of threat and danger. The sentimentality that drew her to him at the beginning is supplanted by qualms and fear which lead to a tragedy Yanko's meaningless death.

The story is narrated by a local doctor called Kennedy, who treated Yanko soon after his arrival, and who is talking to an unnamed frame narrator. The doctor seems to be the only person who understood the oppressive heaviness of Yanko's situation. In his own words, “[i]t is indeed hard upon a man to find himself a lost stranger, helpless, incomprehensible, and of a mysterious origin, in some obscure corner of the earth" (ibid., emphasis added). As the choice of words demonstrates, the doctor is attempting to tell the story from Yanko's point of view to bring forth the feeling of alienation and solitariness experienced by the confused emigrant. Despite his attempts to assimilate and learn the English language, Yanko never becomes part of the local community; the reluctance and unwillingness to accept him renders him a permanent outcast. Clearly, Yanko's “experience demonstrates how the rules of cultural inclusion are simultaneously those that ensure the exclusion of others" (Simmons, 2006, p. 162). The cultural differences and barriers stemming out of them seem to be, in this case, insurmountable.

As all of the abovementioned stories clearly suggest, Joseph Conrad was a writer of the human psyche, deeply concerned with moral consciousness. His insights into the troubling human mind articulate his compassion for mankind and his portrayals render him one of the most influential writers, one whose work resonates with large audiences. Conrad's articulation of his objective as an artist nicely sums up his vision of art and its purpose and provides an appropriate conclusion to the analysis of his selected short fiction:

"A work that aspires, however humbly, to the condition of art should carry its justification in every line. And art itself may be defined as a single-minded attempt to render the highest kind of justice to the visible universe, by bringing to light the truth, manifold and one, underlying its every aspect. It is an attempt to find in its forms, in its colours, in its light, in its shadows, in the aspects of matter and in the facts of life what of each is fundamental, what is enduring and essential - their one illuminating and convincing quality — the very truth of their existence" (Conrad, 1897/1914).

\section{Works cited:}

Billy, T. 1997. A Wilderness of Words. Closure and Disclosure in Conrad's Short Fiction. Texas: Texas Tech University Press.

Conrad, J. 1897. The Lagoon. Available at:

$<$ http://www.gutenberg.org/files/1202/1202-h/1202-h.htm\#link2H_4_0007>

Conrad, J. 1897/1914. Preface to the Nigger of the Narcissus. Available at:

$<$ http://www.gutenberg.org/files/17731/17731-h/17731-h.htm\#link2H_PREF>

Conrad, J. 1901. Amy Foster. Available at: 
$<$ http://www.gutenberg.org/files/495/495-h/495-h.htm>

Conrad, J. 1916. The Tale. Available at:

< http://www.gutenberg.org/files/17732/17732-h/17732-h.htm\#link2H_4_0003>

Davies, L. \& Gene M. Moore (eds.). 2008. The Collected Letters of Joseph Conrad. Volume 8. 1923-1924. Cambridge: Cambridge University Press.

Fraser, G. 1996. The Short Fiction. In: J.H. Stape (ed.) 1996. The Cambridge Companion to Joseph Conrad. Cambridge: Cambridge University Press, pp. 25-44.

Simmons, A. 2006. Joseph Conrad. New York: Palgrave Macmillan.

\section{Simona Klimková}

Department of English and American Studies

Faculty of Arts

Constantine the Philosopher University in Nitra

Štefánikova 67

94974 Nitra, Slovakia

sklimkova@ukf.sk

\section{Acknowledgment}

This work was supported by a grant of the project UGA II/12/2013 - Tradícia a súčasnost': klasická anglofónna literatúra v kontextoch 21. storočia. 